\title{
Editorial
}

\section{Revista Conversas e Controvérsias - v. 6, n.2, 2019}

\author{
Conversations and controversies (Journal) - v. 6, n.2, 2019
}

Teresa Cristina Schneider Marques

Editora

O presente número da revista Conversas e Controvérsias apresenta importantes mudanças na equipe editorial. O número 2 de 2019, o sexto volume digital da revista, marca o acolhimento de uma nova equipe de editores. Como editor, a revista passa a contar com o professor Augusto Neftali Corte de Oliveira e com Marcos Paulo dos Reis Quadros como editor assistente. O professor Augusto Oliveira é doutor em Ciência Política pela Universidade Federal do Rio Grande do Sul (UFRGS) e professor adjunto da graduação e do programa de pós-graduação em Ciências Sociais da Pontifícia Universidade Católica do Rio Grande do Sul (PUCRS) desde março de 2018. Por sua vez, Marcos Quadros é doutor em Ciências Sociais pela PUCRS e bolsista de pós-doutorado no programa de pós-graduação em Ciências Sociais da mesma universidade desde 2019.

As mudanças também afetaram a equipe de apoio técnico e o conselho editorial da revista. No presente número, nos despedimos de estudantes da pós-graduação da PUCRS que desenvolveram um papel inestimável enquanto fizeram parte da equipe. São elas: Taiane Fabiele da Silva Bringhenti e Suliane Cardoso. Taiane Bringhenti foi membro ativo em todos os números desde que se juntou à equipe em 2017, mas se destacou pelo apoio ao dossiê "Partidos e representação política”, organizado por Rafael Madeira, Marcos Paulo dos Reis Quadros, Karolina Roeder e Vinícius Zuccolotto (Madeira, Quadros, Roeder, Zuccolotto, 2018). Cardoso, por sua vez, também muito ativa na revista, ofereceu apoio significativo ao dossiê temático do presente número. Quanto ao conselho editorial, há duas mudanças: a saída de Guillaume Leturcq, colaborador da revista desde 2018, hoje, professor da Universidade Federal do Rio Grande do Sul (UFRGS) e de André Dirceu Gerardi, que, antes de compor o conselho editorial, compôs a equipe de apoio técnico e inclusive organizou o dossiê "Velhas e novas elites na América Latina", juntamente com Fran Spinoza (GERARDI, A.; SPINOZA, 2017). Gerardi passou a atuar na revista em 2016 e atualmente realiza pós-doutoramento na Universidade de São Paulo (USP).

Trata-se também do último número com a minha participação como editora. Após quase cinco anos à frente da revista, me desligo da equipe editorial de Conversas e Controvérsias com orgulho 
pelo percurso traçado pela revista nesse período. A publicação, que já existia em versão impressa de forma irregular antes do seu primeiro número em versão digital em 2010 (ROSS, 2010), se manteve desativada por cerca de 4 anos, entre 2011 e 2015. Sua retomada foi motivada pelos alunos do programa de pós-graduação em Ciências Sociais da PUCRS, egressos do curso de graduação em Ciências Sociais da mesma instituição, que, com o apoio do então coordenador do curso de graduação, professor Me. Roque Dal Ross, confiaram a mim a tarefa de retomar a revista.

Quase cinco anos depois, a revista Conversas e Controvérsias tem o mérito de ter alcançado a periodicidade semestral, três seções consolidadas, uma nova marca visual, uma página no facebook com mais de 800 seguidores, DOI, avaliação pelo sistema qualis-capes, entre outras vitórias. Mas sobretudo, cabe destacar o caráter vanguardista assumido pela revista entre as revistas discentes da área, ao implementar um modelo raro de gestão, marcado pela integração de professores, alunos de pós-graduação e de graduação em todas as etapas de editoração e também nos artigos. Todas essas mudanças foram estabelecidas de forma democrática com a equipe editorial, composta basicamente por estudantes da PUCRS e me sinto honrada por ter participado desse processo.

Tal integração entre pesquisadores em diferentes estágios de formação é verificada no número 02 de 2019, que apresenta o dossiê intitulado "Biografia e sociedade", o penúltimo dossiê submetido à chamada pública que foi publicitada em 2017, organizado por pesquisadores vinculados à PUCRS e à Universidade de Göttingen, na Alemanha. São eles: Hermílio Santos, Doutor em Ciência Política pela Universidade de Berlin e professor adjunto do programa de pós-graduação em Ciências Sociais da PUCRS; Naida Menezes, doutora em Ciências Sociais pela PUCRS, Lucas Sangalli, mestre em Ciências Sociais pela PUCRS e doutorando em Sociologia pela Universidade de Göttingen e, Priscila Susin, doutora em Ciências Sociais pela PUCRS. Na apresentação, os organizadores realizam um breve debate sobre as contribuições da pesquisa biográfica, concebida na vertente sociológica interpretativa, além de apresentar os três artigos que compõem o dossiê.

Além do dossiê temático, o presente número mantém ainda as sessões que foram adotadas a partir de 2016. Em "Artigos livres", contamos com o artigo intitulado "Migrações e meio ambiente: desafios contemporâneos e o debate acerca dos 'refugiados ambientais'” de autoria de Bruna Gorgen Zeca e Carolina Cunha Cesar. Na mesma sessão, contamos também o artigo "Proteger para não destruir: O Protocolo de Madri contra a exploração mineral na Antártica" de autoria de Luiane Magalhães Dias. Finalmente, em "Resenha", o texto intitulado "A ressignificação dos termos cidadania, Sociedade civil e participação: uma análise à luz 'Da cidadania num universo relacional'”, uma resenha crítica que revisita o capítulo "Da cidadania num universo relacional" que compõe a obra de Roberto da Matta intitulada "A casa e a rua: espaço, cidadania, mulher e morte no Brasil ", publicada originalmente em 1984. Em geral, a revista Conversas e Controvérsias não publica resenhas de capítulos, todavia, diante da atualidade e pertinência do texto em questão, considerado um clássico por muitos especialistas, a resenha de autoria de Bruna Hamerski foi considerada uma importante contribuição pelos editores e pelos pareceristas anônimos e, por isso, compõe o número atual.

Pesquisadores de diferentes instituições, no Brasil e no exterior, contribuíram com o presente número. São elas:, Universidade de Buenos Aires, Universidade Nacional de Brasília (UNB), Universidade Federal do Rio Grande do Sul (UFRGS) Pontifícia Universidade Católica do Rio Grande 
do Sul (PUCRS) e National Scientific and Technical Research Council (Argentina) e Universidade de Göttingen (Alemanha). Os resultados de pesquisas apresentadas no presente número foram financiados por diferentes agências de fomento, a saber: Comissão de Aperfeiçoamento de Pessoal de Ensino Superior (CAPES) e Conselho Nacional de desenvolvimento Científico e Tecnológico (CNPq).

Por fim, os agradecimentos. Além de agradecer aos organizadores do dossiê temático e autores que contribuíram com o número 2 de 2019, quero agradecer as estudantes do programa de pós-graduação em Ciências Sociais da PUCRS que compõem a equipe e que se empenharam sobremaneira na editoração do presente número: Suliane Cardoso e Karina Schuch Reif. Para finalizar, um agradecimento especial aos estudantes da graduação e da pós-graduação que fizeram parte da equipe da revista ao longo desses anos no qual compus a equipe, por todo o aprendizado compartilhado que teve como resultado a nossa revista, principalmente aqueles que se despedem da revista juntamente comigo. É uma pequena, mas importante contribuição para a democratização do campo acadêmico em um momento no qual defender o conhecimento se tornou uma tarefa urgente para os cientistas sociais. No mais, desejo aos novos editores um bom trabalho e vida longa à revista discente Conversas e Controvérsias!

Boa leitura à todos!

\section{Referências}

GERARDI, A.; SPINOZA, F. Apresentação: Velhas e novas elites na América Latina. Conversas e Controvérsias, Porto Alegre, v. 4, n. 1, p. 01-04, jan./jul. 2017. Disponível em: http://revistaseletronicas.pucrs.br/ojs/index.php/conversasecontroversias/article/view/28977/16078. Acesso em: 11 dez. 2019.

MADEIRA, R.; QUADROS, M.; ROEDER, K.; ZUCCCOLLOTO, V.. Apresentação: Partidos e representação política. Conversas e Controvérsias, Porto Alegre, v. 5, n. 2, p. 222-231, ago./dez. 2018. Disponível em: http://revistaseletronicas.pucrs.br/ojs/index.php/conversasecontroversias/article/ view/33079. Acesso em: 10 dez. 2019. https://doi.org/10.15448/2178-5694.2018.2.33079

ROSS, R.V. Apresentação. Conversas e controvérsias, Porto Alegre, v. 1, n. 1, p. 1-3, 2010. Disponível em: http://revistaseletronicas.pucrs.br/ojs/index.php/conversasecontroversias/article/view/6879/5002. Acesso em: 06 dez. 2019.

Recebido: 06/12/2019

Aceito: 06/12/2019

\section{Biografia do Autor}

\section{Teresa Cristina Schneider Marques}

Doutora (2011) em Ciência Política pela Universidade Federal do Rio Grande do Sul (UFRGS), com estágio doutoral no Institut d'Études Politiques de Paris (Sciences Po). Coordenadora do curso de graduação em Ciências Sociais da Pontifícia Universidade Católica do Rio Grande do Sul (PUCRS). Professora adjunta do Programa de Pós-graduação em Ciências Sociais da PUCRS. Editora da Revista 
Conversas e controvérsias entre 2015 e 2020. ORCID: http:/orcid.org/o000-0002-6038-2704; E-MAIL: teresa.marques@pucrs.br.

Instituição: Pontifícia Universidade Católica do Rio Grande do Sul.

Localização: Av. Ipiranga, 6681 -Partenon - Porto Alegre/RS 